\author{
Semen V. Yankevich \\ National Research University \\ Higher School of Economics Moscow
}

\title{
Legal regulation of the principle of transparency in the budgetary process of the Republic of Poland ${ }^{1}$
}

\section{Introductory remarks. The legal basis for access to information about the activities of public authorities}

The study of the organizational and legal basis of the principle of transparency of the budgetary process and the research methodology of its provision is impossible without an analysis of the constitutional foundations of the right to information in general. The conditions of the modern world lead governments of different countries to work towards fulfilment of the principle of free public access to public information. Creating the most convenient, least expensive implementation mechanisms for the citizen's rights is a priority for the majority of developed countries. The problem of implementation of the principle of transparency (openness) ${ }^{2}$ has acquired a new meaning after the proclamation of the right to information in international legal acts.

In 1948, the General Assembly of the United Nations ${ }^{3}$ in article 19 of the Universal Declaration of Human Rights established that:

Everyone has the right to freedom of opinion and expression: this right includes freedom to hold opinions without interference and to seek, receive and impart information and ideas through any media and regardless of frontiers.

This international law norm has become the basis for the establishment of the right to information and has been reproduced in the constitutions of many states adopted after

1 In this paper the results obtained in the course of the project "Legal regulation of the principle of transparency of the budgetary process in the Republic of Poland" have been used. The project was implemented within the framework of a scientific grant from the Queen Jadwiga Fund of the Jagiellonian University, awarded in 2012.

2 In international practice, most used the term "transparency".

3 Hereinafter - the UN. 
the coming into force of the Universal Declaration (e.g., article 29 of the Constitution of the Russian Federation, article 34 of the Constitution of Ukraine). Subsequently, the right to information has been reflected in article 10 of the Convention for the Protection of Human Rights and Fundamental Freedoms of 4 November 1950, where it was stated that "everyone has the right to freedom of expression. This right includes freedom to hold opinions and to receive and impart information and ideas without interference by a public authority and regardless of frontiers. The exercise of these freedoms, may be subject to such formalities, conditions, restrictions or penalties as are prescribed by law and are necessary in a democratic society in the interests of national security, territorial integrity or public safety, for the prevention of disorder or crime, for the protection of health or morals, the protection of the reputation or rights of others, for the prevention of the disclosure of information received in confidence, or for the maintenance of the authority and impartiality of the judiciary".

Today, about 100 countries have special laws regulating citizens' access to government information. The first similar law - the Law "About transparency of public documents" - was adopted in Finland in $1951^{4}$. In Poland, the right of citizens to access public information was established in the Constitution of the Republic of Poland of 2 April 19975, which states that everyone has the right of access to official documents relating to its collection and data. This right can only be limited by law ( $\S 3$, article 51$)$. The principles and order of data collection, as well as open access to it, are defined by law. The provisions of article 51 of the Constitution detail the Law of the Republic of Poland of September 6,

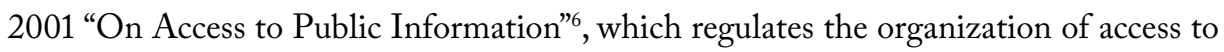
information, cases of restrictions on the right to information and the other most important elements of the legal regulation of access to public information.

In the law of the Republic of Poland the notion of transparency (openness) is denoted by several terms most often used in this sense in the regulatory acts and research: "jawność" and "przejrzystość" (comprehensibility, clarity, explicitness). The activities of the parliament, the government and other public authorities are now largely predetermined by a principle called "jawność" (the principle of publicity). Often in the Polish juridical literature, one encounters the opinion that the principle of transparency is - one "of the most effective guarantors of democracy"

Initially, the principle of transparency in Poland was connected with the activities of representative bodies. According to Polish lawyer Bogusław Banaszak, thanks to modern media and the direct broadcasts of parliamentary sessions, society not only gets information about their work, but, primarily about the opinions they express through their

4 S. Andreev, Public participation in the budget process, Saint-Petersburg 2010, p. 179.

5 Dz. U. $1997 \mathrm{nr} 78$ poz. 483.

6 Dz. U. 2001 nr 112 poz. 1198.

7 A. Jamróz, Demokracja wspótczesna. Wprowadzenie, Białystok 1993, p. 137. 
elected representatives, meanwhile, the activities of other public authorities, in particular, the executive authorities are bound by confidentiality of information ${ }^{8}$.

I believe that in order to better explain the principle of transparency, we should apply the legal regulation of the broadcasts from the sessions the lower house of Congress the House of Representatives. As an example, in paragraph " $b$ ” $\S 4$ of section 11 of the Rules of the House of Representatives of the U.S. Congress, it was established that broadcasting must be carried out by at least two TV stations and two radio companies. Broadcasting cannot be interrupted by advertising. The prohibition of video recording or transcribing of conduct for party purposes was also introduced ${ }^{9}$. In the Republic of Poland, the citizens' right to public information is guaranteed to everyone, and is implemented in accordance with the Law “On Access to Public Information”. In $§ 1$, article 2 of the Act was established an important position on the basis of which the person who is exercising the right to public information is not required to perform any legal action, including providing payment for the information, by the authorities. Thus, the law defined one of the essential conditions - the free provision of such information.

The Law "On Access to Public Information" listed entities who are required to provide citizens with public information. According to $\S 1$ of article 4 of the Act such entities include:

- Public authorities;

- Bodies of economic and professional self-government (e.g., trade unions);

- The Ministry of the State Treasury of the Republic of Poland and other public authorities, representing its interests;

- Government entities and entities of municipalities (here one can make a comparison with state and municipal unitary enterprises whose status is regulated by article 113-115 of the Civil Code of the Russian Federation).

It should be noted that the list of entities that are obliged provide public information is not closed. According to the cop. $5 \S 1$ article 4 of the Law "On Access to Public Information" they also include "persons and organizations that perform public functions or dispose of public property”. Thus, in the Resolution of November 16, 2011 II So / Kr 11/11, the Provincial Administrative Court in Kraków ordered the director of a private pre-school educational institution to grant the applicant the required information about the activities of such an institution. Thus, the court analyzed the status of a legal entity, and included it in the list of those obliged to contribute to the implementation of the right of citizens to information based on the performance of public functions and disposal of public property ${ }^{10}$. Or, for example, in the Resolution of September

$8 \mathrm{~V}$. B. Banaszak, Porórwnawcze prawo konstytucyjne wspótczesnych państw demokratycznych, Kraków 2008.

9 Rules of the House for the 112th Congress.

10 II So/Kr 11/11. 
7, 2011 II SAB / Rz 58/11, the Provincial Administrative Court in Rzeszów recognized the obligation of a deputy of a local council to provide information at the request of the applicants, despite the fact that it is not listed among the entities named in cop.1-4 Section 1, article 4 of the Law "On Access to Public Information"11.

The analysis of judicial practice that has developed since the adoption of the Law "On Access to Public Information”, often shows that such entities as private entrepreneurs, charities, universities, political parties, religious and other community organizations are attributed ${ }^{12}$. In general, it should be noted that the courts usually take the position of the applicants and stand up for their right to public information, except in cases where disclosure of such information poses a danger to the stability of the state's political and economic system. However, Polish constitutionalist Wiesław Skrzydło notes that the authorities cannot arbitrarily order a particular amount of information to be disclosed, or provide a list of the documents where access is to be restricted or denied. Such a restriction of the right to information is possible only on the basis of law, based on the purpose of ensuring the security of the state and economic stability ${ }^{13}$.

The doctrinal position is fully reflected in the legislation of Poland. In accordance with $\S 3$ of article 51 of the Constitution of the Republic of Poland, the right of access to official documents and data can only be restricted by law. This constitutional provision is developed in article 5 of the Law "On Access to Public Information", which established the limits to the right to public information. Firstly, such restrictions are dictated by the presence of the legal system of confidentiality, extending to statutory information. In particular, access to information is subject to restrictions regarding the private life of an individual (article 49 of the Constitution of the Republic of Poland), trade secrets (article 551 of the Civil Code from April 23, 1964'4) and professional confidentiality (article 6 of the Act of May 26,1982 "On the Bar"15). The exceptions to this rule are persons who perform public functions, but only within the boundaries of information associated with those functions.

Secondly, the spread of information is limited if it could harm the economic interests of the state through:

- The creation of insurmountable difficulties for the negotiations of the Ministry of the State Treasury of the Republic of Poland in the process of applying their powers in the management of state property, in the fulfilling by the Republic of Poland of international agreements or decisions of the European Council or the Council of the European Union;

11 II SAB/Rz 58/11.

12 M. Kłaczyński, Komentarz do Ustawy o dostępie do informacji publicznej, Warszawa 2003.

13 W. Skrzydło, Komentarz do Konstytucji Rzeczypospolitej Polskiej, Kraków 2002.

14 Dz. U. 1964 nr 16 poz. 93.

15 Dz. U. 2009 nr 146 poz. 1188. 
- The creation of difficulties regarding the property interests of the Republic of Poland and the protection of the interests of the Ministry of the State Treasury of the Republic of Poland in proceedings in a court or administrative order.

Also, in view of the provisions mentioned above in article 5 of the Law "On Access to Public Information" it was established that information on cases before the courts in civil, administrative or criminal proceedings against public authorities or persons exercising public functions is not to be limited. Section II of the Law "On Access to Public Information" details the procedure for providing public information. In particular, the purpose of the use of such information (for personal use, for the preparation of regulations, etc.) was established. Such data shall be published in the Bulletin of Public Information. If they are not published in the Bulletin, they should be promptly submitted to the applicant orally or in writing, taking into account the established limits and upon his request. In accordance with article 13 , requested information should be submitted to the citizen not later than 14 days from the date of submission of the application. However, the competent public authority has the right to extend this period for up to two months, but must notify the applicant beforehand. In addition, refusal must be properly formalized. In the absence of the necessary administrative decisions, refusal is unlawful.

Finally, the Law "On Access to Public Information" establishes the liability of public authorities for wrongful denial of access to public information. Often, the public authorities provide incomplete information or information that is different from that which the applicant requested and this becomes the subject of itigation. Thus, the Provincial Administrative Court in Warsaw, in a judgment of 9 December 2010 II SAB / Wa 280/10, indicated that the presentation of information other than that which the applicant is awaiting, or incomplete information cast doubt on the performance of public authority requirements for providing access to public information. The court ordered the head of the gmina ${ }^{16}$ to provide the requested information to the applicant and to pay a penalty in his favor ${ }^{17}$.

Thus, the principle of transparency of the budgetary process is related, in my opinion, with the constitutionally guaranteed right to information as well as the obligation to provide access to public information on the financial activities of the state at all stages of the budgetary process. And if even half a century ago, in many European countries, satisfaction of the public interest in fields of public expenditure was reduced to the discretion of the State to provide such information or not, today the principle of fiscal transparency has become the responsibility of public authorities.

Since Poland is taking part in well known integration processes, like other European Union countries, acts according to supranational legislation when it comes to the regulation of many matters, therefore it is necessary for Poland to designate the levels 
of the legal regulations of its institutions, in order to allow an analysis of the structure of the implementation of the principle of transparency of the budgetary process. The agreements on stability, coordination and management in economic and currency union, that are aimed at reinforcing budgetary discipline and introducing stricter control in the Eurozone, comprise one of the greatest aims of the provision of transparency of the budgetary process ${ }^{18}$.

Being a member of The International Monetary Fund (IMF) since 1986 and of the Organization for Economic Cooperation and Development (OECD) since 1996, Poland also incorporates documents adopted by these international organizations into national legislation, despite their recommendatory nature. In this way, Poland is working to become a part of the national legal system of the provision adopted in 1998 by the IMF Interim Committee of Code of Good Practices on Transparency in the fiscal domain ${ }^{19}$ and the best practices of OECD for transparency of the budget, adopted in September 2000.

Ie believe that the use of such documents is very important for countries aiming to achieve the maximum transparency in public finance due to the following reasons. Firstly, the Code of the IMF and the Practice of the OECD are perfect examples and templates by which national legislation can be brought in line with international regulations. Furthermore, it is difficult to ignore the demands of the provision of transparency of the budgetary process for countries that are bound by international agreements, including agreements on accession to the OECD and the IMF. Finally, within framework of the IMF and the OECD, it will be possible to achieve a relatively unified legal regulation of the institution of the budget law and a smoother and more progressive implementation of the principle of transparency of the budgetary process.

\section{Legal foundation of the principle of transparency of the budgetary process in the Republic of Poland.}

According to $\S 1$ of the Constitution of the Republic of Poland, funding for public purposes is being collected and spent in the manner specified by the law. The law, which determines the amount of revenue and expenditures of the state, the method of the government's borrowing and loans and the regulation of the budgetary processes, in accordance with the Constitution, is the Law of 27 August 2009 "On the public finances"20. Prior to that, the legal regulation of the financial matters of the state was carried out by the Law of 30 June 2005 "On the public finances" 21 , which is no longer valid, apart from a few articles.

18 Treaty on Stability, Coordination and Governance in the Economic and Monetary Union.

19 Hereinafter - the Code of IMF.

20 Dz. U. 2009 nr 157 poz. 1240.

21 Dz. U. 2005 nr 249 poz. 2104. 
One of the incentives to adopt the 2005 "On public finances" Law, was a desire to provide transparency in public finances, in order to implement the constitutional right of citizens to access information. The explanatory note accompanying the bill states that: "Only the transparency of public finances, achieved by constant publication of relevant reports, can protect the coffers from the prodigality and frivolity of the authorities, as well as prevent disorder and corruption. The transparency of budget matters is the foundation of a modern democratic country, and serves as a significant source of strength for the citizens"22.

The Law "On public finances" from 2009 has maintained the trend initiated in the previous Law "On Public Finance" from 2005. The Polish legislator has defined the concept for the organizational and legal bases of the principle of transparency in the budget process with the terms "jawność" and "przejrzystość", covered by section 4 of the Law "On public finances". It is stated in $\S 1$ of the Law "On Public Finance", that all activities related to public finances should be transparent. This means an ability to obtain free access to information about all financial transactions.

The notion of transparency of budgetary processes is subdivided into the formal and material senses in the academic literature ${ }^{23}$. The transparency of budget processes, in a formal sense, provides for transparency of public authorities in the area of public finance, and can be implemented, for example, through parliamentary debate at the stage of the budget project being under consideration, being approved and being implemented. The procedures of parliamentary debates are described in detail in the Rules of the Lower House of Parliament of the Republic of Poland, approved by the Resolution of the Lower House of Parliament of the Republic of Poland on 30 July 1992 24 . The transparency of the budgetary processes, in the material sense, is the ability to analyze operations within the budget. In order to fully implement the principle of transparency, the budget execution reports should be as detailed and easy to understand for most citizens as possible. It is not accepted when the transparency and accuracy of financial performance requires citizens to possess a set of special skills and knowledge in the field of financial law or economics.

A system of budgetary accounting reporting, and budget classification, is extremely important within this context. It is no coincidence that the laws of many states repeat the succession of budget classification, contributing to the comparison of budgetary performance during different financial years, and a more complete picture of the income and expenses of a public legal process. It is possible to be exempt from the regulations

22 Uzasadnienie z dnia 23 kwetnia 2005 r. do projektu ustawy o finansach publicznych.

23 C. Kosikowski, Finanse publiczne w świetle Konstytucji RP oraz orzecznictwa Trybunatu Konstytucyjnego, Warsawa 2004, p. 107; L. Lipiec-Warzecha, Kommentarz do ustawu z dnia 27 sierpnia 2009 r. o finansab publicznych, Warsawa, 2011.

24 M.P. $1992 \mathrm{nr} 26$ poz. 185. 
on $\S 1$, of the Law "On Public Finance" in cases where it is necessary to refrain from publishing different kinds of documentation, which may contain, among other things, statistics on the financial performance of the country, due to specific rules or regulations in international treaties.

Special provisions are set out in the Act of August 5, 2010 "On the protection of classified information" ${ }^{25}$, Law of 25 June 1997 "On the main witness" ${ }^{\text {"26 }}$, and the Act of 29 August 1997 "On Protection of Personal Data"27. According to $§ 5$ of the Law "On protection of classified information" information that could pose a threat to the independence, sovereignty or territorial integrity of the Republic of Poland, internal security and the constitutional order, as well as the international situation of the state, or weaken the country's defence, cannot be distributed.

The legislation is not only limited by the proclamation of the principle of transparency in the budgetary processes. There are specific requirements set in $\S 34$ of the Law "On Public Finance", on the openness of the budgetary processes. First of all, the procedure of consideration of the draft budget, the adopted budget, the discussion and approval of the budget execution reports in the Lower House of Parliament and the Senate, as well as representatives of local self-government shall meet the requirements of openness. Next, the information that is allowed to be published is: the long-term financial plans of municipalities; the amount of subsidies allocated from the state budget and the budgets of municipalities; subsidies allocated from the state trust funds; monthly reports on the current budget. Then, the mandatory disclosure data is: information concerning contracts concluded with private sector organizations to provide social services; information on the amount of funds allocated for the payment of budgetary obligations of public law entities; information that serves as a proof of the implementation of socially significant services and their payments. Moreover, the officials of the National Health Fund must prove the transparency of their operations through: the publication of data on the sources of revenue and expenditure, details of the Fund agreements, their significant conditions and costs. This obligation is also adopted in a special Act of 27 August 2004 "On health care at the expense of public finances" ${ }^{28}$. The article 135 of the Act stipulates that the National Health Fund implements the principle of transparency, particularly through the publication of information about the concluded agreements on their services, as well as goods delivery with the cost and the quantity on its official website. Such information will be made public no later than 14 days from the date of contracting. The requirement for transparency is also contained in the Charter of the National Health Fund, approved by the Decree of the President of the Council of Ministers of the Re-

25 Dz. U. 2010 nr 182 poz. 1228.

26 Dz. U. $2007 \mathrm{nr} 36$ poz. 232.

27 Dz. U. 2002 nr 101 poz. 926.

28 Dz. U. $2004 \mathrm{nr} 210$ poz. 2135. 
public of Poland on September 29, 2004 ${ }^{29}$. ften, a failure to provide information to the officials of the National Health Fund is a subject of litigation. For instance, according to the Provincial Administrative Court in Warsaw, the Minister of Health of the Republic of Poland on the basis of article 167 of the Law "On health care at the expense of public funds", has fined the head of the Lower Silesia provincial office of the National Health Fund for failure to release information specified by law, on the official website of the Department of the Foundation ${ }^{30}$.

Then, the transparency of the budget processes is achieved through the publication of a list of persons to whom the budget of the State or municipal budgets have been allocated grants or funds to co-finance the performance of statutory functions. ext, the annual reports on the financial performance of public authorities are subject to mandatory disclosure. Furthermore, the public authorities are obliged to provide public access to the data of budgetary accounting and reporting records of the results of the audit authorities to verify the intended use of the budget; the audit report on the financial performance report for the previous financial year. Moreover, a report on the implementation of the budget for the previous fiscal year and the proposed budget for the next fiscal year should be published in the Bulletin of Public Information.

However, the principle of transparency, including the area of financial activity of the State, has legal limits related to the protection of the rights and interests of citizens, organizations and the government. Article 35 of the Law “On Public Finance”, requires compliance with the legal restrictions on transferring information, such as trade secrets, during the implementation of the principle of transparency of public finances. The list of responsibilities of public authorities involved in the budget process is provided in article 36 of the Act, the execution of which contributes to the realization of the principle of fiscal transparency.

Thus, according to the $\S 1$, the Minister of Finance of the Republic of Poland must present the following documents to the public:

- Information on the financial performance of public authorities, including information on commitments and guarantees made;

- Monthly operational reports on the budget with the mandatory reflection of the amount of deficit or surplus of the budget;

- A list of businesses and individuals which were given guarantees or collateral by the Ministry of the State Treasury of the Republic of Poland in order to ensure fulfilment of the obligations.

These documents shall be published in the official edition of "Monitor Polski" annually by 31 May of the following year. In addition to this, according to article 38 the Minister of Finance will publish information on the ratio of GDP and public debt of the state 
of the Republic of Poland, the aggregate debt of the Ministry of the State Treasury of the Republic of Poland, the amount of guarantees and sureties granted to companies and individuals by the Ministry of State Treasury, in order to ensure the fulfilment of obligations. It should be noted that the requirement for the publication of such data does not arise from the principle of transparency of the financial activities of the state, but from the provisions of Section 5, article 216 of the Constitution of the Republic of Poland, which prohibits borrowing or providing financial guarantees and sureties, that can result in the state public debt exceeding three fifths of GDP. In this case, we believe, such a rule is in place in order to prevent the country being in a debt that exceeds the norm, which could threaten the country's economy and, as a consequence, the sovereignty of the state.

According to Skrzydło, analysis of financial performance of state power in recent years shows that the figures indicated above do not exceed the allowed limit of the Constitution $^{31}$. The Law "On Public Finance" establishes the executive bodies of local self-government, aimed at implementing the principle of transparency in the budget process. In general, the provisions of this article are similar to the duties of the Minister of Finance of the Republic of Poland, provided in article 34, 36 and 38 of the Law "On public finances". It should be noted that during the development of the new Law "On Public Finance" in 2009, the legislator made separate provisions for municipalities for the first time.

Article 37 of the Law "On Public Finance" defines the terms of disclosure of information on the financial performance of a municipality: Firstly, before the end of the month following the end of the quarter, the executive body of the local self-government shall publish a report on the implementation of the operational budget. The report must include information about collected revenues and expenditures, information about changes introduced into the budget during the reporting period, as well as data about the existing deficit or surplus of the budget. Then, by 31 May of the following year, the executive bodies of local self-government shall disclose:

- A report on the budget of the municipality in the previous fiscal year, with the obligatory indication of the budget surplus or deficit;

- A report on the use of the amounts of money allocated from the budget of the European Union;

- Information on the amount of liabilities not covered by the budget of the municipality, arising from the decisions of the courts;

- A report on the use of funds from the budgets of other municipalities, as well as data on the amounts of grants provided by the municipalities to other municipalities;

- A list of businesses and individuals, which are provided with guarantees or collateral by the executive authorities of local government, as well as the amount of such representation or warranty;

31 W. Skrzydło, op.cit., Krakow 2002. 
- A list of businesses and individuals who have been granted tax relief and which are provided with the amended terms of tax obligations, including the provision of instalments or deferred payments, if the amount of taxes that make up such benefits exceed PLN 500. Not only should the basic amount of debt to pay taxes be taken into account, but also the amount of interest on the instalment plan to pay the tax ${ }^{32}$. Providing tax relief to taxpayers must be justified and documented. Such a detailed list of responsibilities of public authorities that are parties to the budget process, fully meets the requirements of Section I "Clarity of roles and responsibilities" Code of the IMF.

\section{Conclusion}

Contemporary analysis of the legal regulation of the principle of transparency in the budget processes in the Republic of Poland shows that it is complete and makes sense. However, it is not possible to perceive this principle in isolation from constitutional law without damage to the proper understanding of the legal nature of the principle of transparency in the budget process and the development of the methodology for its implementation. It can be assumed that the right of citizens to have access to information on the activities of public authorities in the area of public finance was predetermined by the right to information in general. The Law of the Republic of Poland "On the public finances" contains a detailed list of procedures, actions of state and local governments to ensure the openness of operations within budgetsand lists the types of reports and other requirements for the persons taking part in the budget process. It should be noted that the principle of transparency in the budget processes is achieved not only by publishing budget reports and other information on the financial activities of the state, but also other elements of the budgetary process: budget classification, the cash execution of the budget, budget accounting. Thus, we can see a direct link between a transparent budget process and the possibility of free access to information on past, current and future activities of the state in the field of public finance, information on the structure and powers of public authorities and other participants in the budget process, on the objectives and results of financial activities of the state, and the implementation of proper legal regulation and the adoption of effective measures aimed at improving the transparency of public finances at each stage of the budget process.

32 Dz. U. 2009 nr 157 poz. 1240. 
226 | Adam Mickiewicz University Law Review

\section{Summary}

\section{Legal regulation of the principle of transparency in the budgetary process of the}

\section{Republic of Poland}

The article describes the organizational and legal foundation of the principle of budget transparency in Poland. The study considers the legal basis for access to information about the activities of public authorities and the legal foundation of the principle of transparency of the budgetary process in the Republic of Poland. The main instruments for achievement of transparency of all operations with public funds such as budget classification, the cash servicing of budget implementation, budget accounting and reporting are analysed. While attempting to describe the aforementioned matters, the author proposes a definition of the term "budget transparency".

KEYWORDs: budget process; transparency; budget classification; cash servicing; accounting and reporting. 